\title{
The Case of Goa: History, Rhetoric and Nationalism
}

\section{Philip Bravo}

ABSTRACT: The Indian armed forces "liberation" of the small Portuguese colony of Goa in 1961 put an end to a fruitless diplomatic contest between New Delhi and Lisbon. The arguments used by each government to defend its right to Goa provide an interesting case study of how history can be used in an attempt to define a "people." Since few Goans were persuaded to make a stand on either side of this debate, this case indicates the limited power of nationalist rhetoric, and therefore the need for historians to look beyond such rhetoric to understand the formation of national identity.

Goa is a small state on the South-West coast of India about 200 miles south of Bombay. It is a popular destination for European tourists who enjoy its unique Indo-European culture.' Although Goa is now without a doubt a part of India, from 1947-1961 this "fact" was not quite so obvious. After 1947 the recently established government of India expected the Portuguese to abandon their 400-year-old colony in India. The Portuguese government, however, refused on the basis that Goa was a province and Goans were Portuguese.

Meanwhile, Goans seem to have been indifferent to this problem. A mass nationalist movement that represented either the Portuguese or Indian position did not exist in Goa. Goan-Indian nationalists were based in Bombay while Luso-Indian nationalists comprised only a very small minority of the Goan population. In 1961, following the Indian "liberation" of Goa and celebrations throughout India, journalists noted an unusual lack of enthusiasm among Goans. ${ }^{2}$ This indifference or apathy had been a source of embarrassment for everyone involved. The failure of nationalist rhetoric to persuade the local population of

Past Imperfect, Vol. 7, 1998, pp.125-154 
Goa to embrace either position is a useful case study to examine the relationship between history, nationalism and rhetoric.

In general, historians have paid little attention to this relationship. Historians of nations and empires have preferred to describe the rise and eventual collapse of empires, while at the same time, describing the "freedom struggle" or emergence of nations within empires. In these national histories nations render empires illegitimate. Recent theories of nationalism have emphasized that nations are "imagined communities," narratives and discourses that are created through language and, depending on the political context, either repressed or enforced by a colonial or national state. Indian scholars have recently described the extent to which historical narratives contribute to either empire- or nation-building.

By trying to describe the debate over Goa and the failure of nationalist rhetoric to persuade a significant number of Goans to imagine that they are Portuguese or Indian, I will examine the relationship between the rhetoric of nationalism and the "people." In doing so, I will show that recent theories of nationalism have placed too much emphasis on the performative aspect of rhetoric; that is, these theories do not account for the day to day organization of people into groups that embrace the idea of national affiliation. This article will answer the following questions: why was an Indian nationalist movement absent in Goa during the debate?; and how did Nehru and Salazar defend their assertions while ignoring the "reality" of Goan indifference to either position? In so doing I will describe how rhetoric failed to persuade an audience. Before I can begin to answer these questions a brief discussion of rhetoric, history and nationalism is necessary.

Rhetoric is usually understood to be a pejorative, but rhetoric is "the art of using language so as to persuade or influence others." Although this definition seems to be 
straight forward the purpose and use of rhetoric has been the centre of controversy for centuries. The essence of the controversy is the relationship between rhetoric and "truth." Plato wrote that rhetoric subverts"truth," while Aristotle responded that it was a tool which reveals "truth." Whether a person agrees with Aristotle or Plato is dependent on ones "thinking" about reality. Is it created through language or is language a humble tool that is able to describe reality? ${ }^{3}$

The ambiguity of rhetoric and its relationship to truth is at the centre of the contemporary controversy about history and nationalism. To illustrate the ambiguous and double-edged nature of nationalism Tom Nairn described nationalism as a Janus faced ideology. Janus, the two faced Greco-Roman god, was able to observe the past and the future and he guarded the gate to war and peace. Janus is an appropriate personification of the double-bind that historians and nationalists confront. Historians have already shown that nationalism and History have had an intimate relationship since the mid-nineteenth century. ${ }^{5}$ To organize the past, historians require a subject that is constant through time. The nation is the most convenient subject to add meaning and order to the past and it has become the most common category or the "master subject" of History. In the context of imperialism, most historical narratives are constructed around the emergence, struggle and "liberation" of nations. Imperialism is, therefore, rendered illegitimate because it subjugates a nation and its "people." Yet, the apologists of imperialism manipulate History to justify the possession of colonies on the basis that they were not nations. ${ }^{6}$

Jawaharlal Nehru, India's first prime minister and second only to Mohandas K. Gandhi in India's "freedom" struggle, understood the ambiguous relationship between History and nationalism quite well. In The Discovery of India Nehru described India in the following manner: "India 
is a geographical and economic entity, a cultural unity amidst diversity... She is a myth and an idea, a dream and a vision, and yet very real and present and pervasive."7

Nehru's definition of nationalism is also clear:

Nationalism is essentially a group memory of past achievements, traditions, and experiences ... One of the remarkable developments of the present age has been the rediscovery of the past and of the nation. ${ }^{8}$

Yet, 36 pages earlier Nehru states: "By writing of the past I have tried to rid myself of the burden of the past." Although the past provides the "group memory" and history necessary to discover a nation, which is a "myth, dream and vision" and yet a "pervasive reality," it is also a burden which has to be forgotten. ${ }^{10}$

These paradoxes and ironies were revealed during the debate between Nehru and the prime minister of Portugal, Antonio Salazar, over Goa. The debate centred around the political, cultural and national identity of Goa. Nehru argued that the Goans were Indians by every standard and Goa was a colony ruthlessly administered by a racist, fascist and colonial regime. Salazar, however, argued that despite Goa's location and Portugal's political system, it was a province of Portugal as integral to his nation as the Algarve. Goans were represented in the Portuguese legislature and some even served in the Portuguese cabinet; they were citizens of Portugal. Salazar, therefore, refused to heed Nehru's repeated bids for negotiations to release Goa from Portuguese sovereignty. On 17 December 1961, after 14 years of fruitless negotiations 30,000 Indian troops, supported by the Indian air and naval forces, marched into Goa to defeat a garrison of 900 ill-equipped Portuguese troops who were ordered to fight to their death. Within two days the Indian government proclaimed, amid great international controversy, the end of colonialism and 
imperialism on the subcontinent. Goa was now, without a doubt, a part of India.

Today this conflict is ignored by scholars interested in India, but it may prove to be a useful case study to examine the use of history in the politics of nationalism to sustain a representation ofa nation. History played a significant role in this debate. As we shall see, Salazar based his conviction on history: the Portuguese had been in Goa for 450 years, while independent India had only just been established. The debate over Goa was the site of a contest that compelled Portuguese and Indian nationalists to defend representations of their nations.

This article is divided into four parts. The first is a brief narrative describing the Portuguese presence in Goa from 1510 to 1950 . The second part is a brief description of the historiography of the debate. This is followed by an overview of the scholarly literature on the relationship between history, nationalism and imperialism. The fourth part is a detailed analysis of the debate itself as it was conducted by the its two main actors.

Goa was a part of the Bijapur sultanate when it was conquered by a Portuguese fleet in 1510. During the sixteenth century Goa was a crucial link in Portugal's mercantilist system, providing a safe port for her ships and access to trade in the subcontinent. The colony was also an important locale for the missionary activities of the Roman Catholic Church. The needs of Church and State met in the colony and engendered an overt and aggressive policy of acculturation and assimilation of the peoples living in Goa. Although this policy eventually failed, a small group of Catholic Goans did form an elite that co-operated with the Portuguese regime. By the beginning of the seventeenth century, Goa's status diminished as the Dutch and British trading companies displaced Portuguese trade. 
The imposition of Portuguese dominance in Goa was met with considerable resistance. The most serious perhaps was the "Conspiracy of the Pintos of Candolim" in 1787. The conspiracy was led by Father Caetano Victorino de Faria in Lisbon and Father José Antonio Gonçalves and Father Caetano Francisco Couto in Goa." The rebels, however, were betrayed by Antonio José Toscano who reported their plans to the Portuguese government. The rebels, 47 in total, were imprisoned and the leaders were executed. Father de Faria, however, managed to escape capture and found sanctuary in Paris where he became involved in "Mesmerism" and the French Revolution."

M.N. Pearson suggests that the cause of the revolt was the failure of the reforms to create a non-racist administration. ${ }^{13}$ The consensus among historians is that the cause of the rebellion was the Portuguese administration's refusal to promote educated Catholic Goans to the higher ranks of its bureaucracy. The rebels intention was to oust the Portuguese and establish a republic. The rebellion also seems to have been influenced by the republican ideals taught to students in the schools established in Goa and Portugal.

Alongside these rebellions was the attempt by some members of Goa's indigenous elite to participate in the colonial and national governments of Portugal. A western educated elite emerged in Goa who tried to reform their relationship with the Portuguese metropole. Before 1820 the Portuguese State of India was in essence a colony governed by an autocratic viceroy appointed to the position by the monarch with no participation from the local population. The constitution of 1822 was passed in Lisbon which defined the Portuguese nation as "the Union of all the territories of both hemispheres."14 Goa, therefore, was considered to be a province of Portugal and as such eligible Goans were allowed to elect three representatives to the Portuguese parliament. Although the voters had to speak 
Portuguese, practice Catholicism and pay substantial taxes, the Portuguese State of India was, unlike any other European possession at the time, considered to be a province with the same status and rights as any other province of mainland Portugal. Surprisingly, despite the restrictions, 40,000 out of a population of 500,000 were allowed to vote. ${ }^{15}$ Ironically, Goans were informed of these reforms and events by someone living in British India. Upon being told of these reforms the governor of Goa, Diogo de Sousa, refused to enforce the constitution because he was waiting for instructions from Lisbon. He was quickly deposed and fled to Bombay. A "governing junta" was established to administer the colony until his successor Manuel de Câmara took his place.

In 1822 the first Goans were elected to the legislature: Bernardo Peres da Silva and Constancio Roque da Costa. The third representative, Antonio Jose Lima Leitao, was Portuguese. ${ }^{16}$ Unfortunately, these representatives never left Goa due to the eruption of an unforeseen counterrevolution in Portugal. In Portugal the constitutional monarchy was almost immediately attacked by the nations conservative or reactionary elites which included the clergy and the nobility. In 1834 Prince Pedro, with the military backing of the British, defeated his brothers army and saved the constitutional monarchy. The restored constitutional monarchy retained the right of Goans to be elected to the legislature in Portugal.

In 1834 , da Silva became the first Goan viceroy of the Portuguese State of India. He immediately initiated a flurry of reforms which alarmed the Portuguese military officers and civilians who seem to have forced da Silva to flee to Bombay. There, he organized a volunteer force of expatriate Goans to defeat the Portuguese rebels. Order was finally restored in 1837 by Portuguese troops. Da Silva returned to Goa and was once again elected to the Portuguese legislature where he was appointed to the 
Standing Committee for the Colonies. As a result of these difficulties the Portuguese government further liberalized the political situation in Goa. On 9 April 1838, a decree was passed in the Portuguese legislature which allowed for the creation of a "popular regime of sorts" in Goa. The council was not a legislative body and it could not amend or propose new legislation. It could only express an opinion and vote on specific legislation brought to it by the government. Although the council had a strictly advisory function it did provide an opportunity for Goans to demand a council that was actually representative of the population."

During this period at least two prominent Goans, a priest and an author, were elected members to the Portuguese legislature. Both declared that Goa, following the example of Brazil, should be permitted to be an independent, sovereign state. In 1852 Father Jeremias Mascenrenhas reportedly said that "emancipation was a natural evolution common to both individuals and colonies." 18 More important, however, was Francisco Luis Gomes, bom in 1829 , and elected to the Portuguese parliament or Cortes in 1860 . While he was in Europe he not only fulfilled his responsibilities as a member of the Cortes, he also wrote several books, including a widely recognized economic treatise and the most popular Goan novel, Os Brahmanes (The Brahmins). ${ }^{19}$ Gomes was also a committed nationalist who struggled to acquire Goa's autonomy. Other Goans however were not eager to secede and willingly accepted government appointments, including cabinet posts. ${ }^{20}$

As a result of these electoral and constitutional reforms political parties and newspapers were established in Goa. These parties and newspapers managed to articulate differing political viewpoints and seek support for political platforms from a proportion of the population. Two distinct parties were established: Partido Indiano (The Indian Party) and the Partido Ultramariono (The Overseas Party). 
The first supported the attainment of greater administrative autonomy for Goa while the latter wished to maintain and strengthen Goa's links to Portugal. These two parties canvassed candidates in almost every election and promoted their opinions through newspapers. ${ }^{21}$

In 1910 official discrimination against Hindus was repealed which in turn led to an outburst of intellectual, cultural and political life in Goa. Unfortunately in 1927, as the political and economic situation worsened in Portugal, a respected professor of economics, Antonio Salazar, assumed the premiership. Salazar was a devout Catholic whose authoritarian, anti-communist and fiercely nationalistic regime governed Portugal until 1974. The arrival of Salazar's regime revoked the constitutional reforms in Goa, as well as its equivalent in Portugal. In 1933 Salazar's Colonial Act rescinded the limited franchise and Goa was considered to be a colony. Many of Goa's indigenous elites, discouraged by this sudden and unexpected reversal, emigrated to Bombay.

It was primarily in Bombay that articulate and prolific nationalist movements arose to challenge Portuguese colonialism. The most influential Goan nationalist, Tristao de Braganca Cunha, established a relationship with the Indian National Congress. ${ }^{2}$ It was his expectation, as well as Nehru's, that once the British had left the subcontinent Goa would be almost immediately abandoned by the Portuguese government. Congress and Indian nationalists in general, therefore, including Braganca Cunha, did not try to organize Goans against the Portuguese state.

In 1949 Nehru's government established a legation in Lisbon to negotiate with the Portuguese government their withdrawal from Goa. To Nehru's surprise, however, the Portuguese government refused to even discuss the issue. By 1953, the Indian legation was closed and diplomatic relations between the governments were conducted by intermediaries. Salazar and Nehru were forced to defend 
their respective positions and persuade an international and national audience of the "truth" of their claims.

Throughout the debate between Salazar and Nehru, Goans seem to have been apathetic to either position. Many Goans ignored the border or used it to their own benefit. The economic blockade against Goa established by Nehru's government in 1955 served to isolate Goa from the Indian economy and strengthen its ties to Portugal. Moreover, an unforeseen economic "boom" arose due to an international demand for lower grade ore which was common in Goa. Suddenly, in marked contrast to the neighboring Indian states, West European luxury goods and jobs with high wages were available to Goans. Goa was enjoying a period of prosperity unseen in India. Yet, the economic link between India and Goa was not completely severed. Smuggling "western goods" to India from Goa became a very profitable trade. Tangled in this web of contradictions, Nehru was compelled to accept the advice of his most prominent minister, Krishna Menon, and "use force."

Although the Goa debate was a minor event in the context of the many formidable problems of post-colonial India, it has received some attention from a handful of scholars. This historiography has been devoted to describing and analyzing the political and diplomatic problems that faced the governments of India, Portugal and their allies. It can be divided into two categories: several articles and a book concerning the debate itself and historical surveys describing the 400-year-old history of the Portuguese territories in India. None of these articles or books discuss the symbolic importance of Goa to either Nehru or Salazar. This is unfortunate because to a large extent Goas symbolic importance may explain Salazar's recalcitrance and Nehru's procrastination.

Arthur Rubinoff's India's Use of Force in Goa is the only book that is exclusively devoted to the controversy 
over Goa. Rubinoff sets out to defend Nehru's action to a "Western" audience. The reaction of the "West," Rubinoff argues, with some justification, was unduly harsh and insensitive to Nehru's moral dilemma. Nehru, who saw India and himself as leaders of the post-colonial world and the representatives of Gandhi's philosophy of "passive resistance" and "moral persuasion," could not hastily invade a territory occupied by a foreign power without being accused of hypocrisy. ${ }^{23}$ This accusation was, however, the most common indictment made against Nehru after the military "liberation" of Goa. Although Rubinoff, acknowledges that the debate between Nehru and Salazar was "without question ... of a symbolic nature" and that both "Portugal, as well as India, viewed the problem in abstract terms" he does not discuss adequately the meaning of the symbol or the terms of the abstraction. ${ }^{24}$

Recently, three articles concerning the debate have been published by other scholars. José Freire Antunes describes Salazar's futile attempts to recruit allies to bolster the position of Portuguese troops in Goa. ${ }^{25}$ The foreign policy of the United States government was ambiguous due to its air force bases in the Portuguese Azores and Portugal's membership in NATO. Moreover, although American foreign policy was anti-imperialist in spirit, it was also vigorously anti-communist. Nehru's foreign policy of non-alignment and his good relations with the Soviet government complicated the relationships between the governments of India, Portugal and the United States. So, Antunes argues: "In Washington there existed a plethora of opinions that fell between John Foster Dulles's clearly proPortuguese statement of late 1955 and the Kennedy administrations tacit anti-colonialism."26

B.S. Shastry tries to place the efforts of a minority of Goans to create a Goan Republic in "a proper historic perspective." He proceeds to describe the many rebellions against Portuguese colonialism from the 1650 to 1961 . 
This article is an example of Indo-centric historiography common among contemporary accounts of the history of Goa during the colonial period. Shastry points out twice in one paragraph that the Goan anti-colonial rebellions occurred "much earlier" than those in British India, yet he does not try answer why a Goan nationalist mass movement never emerged in the Portuguese colony after the end of the Second World War. ${ }^{27}$

The release of the British government's correspondence by the Public Records Office offered Habibar Rahman the opportunity to discuss the role of the British government in the Goa case. ${ }^{28}$ It appears that the policy of the British Foreign Office was to encourage Nehru not to use force to achieve the possession of Goa. The British government, however, was not able to apply too much pressure on a member of the Commonwealth and a former colony. The British position was also complicated by the centuries long relationship with the Portuguese government and Portugal's inclusion in NATO. Rahman, however, avoids the complexity of the Goa case by ignoring those Goans who collaborated with the Portuguese administration and emphasizing only the actions of Goan nationalists.

In addition to these contributions are histories describing the Portuguese presence in India. These surveys are characterized by a preoccupation with either Portuguese or Indian nationalist ideologies and commitments. A sustained effort to demonstrate indigenous resistance to Portuguese colonialism is a common feature of Indian/Goan historiography. The earliest example of such a scholarship is R. P. Rao's Portuguese Rule in Goa. ${ }^{29}$ Published two years after the "liberation" of Goa, Rao tries to persuade the reader that Goa was not isolated from the rest of India. Rao, therefore, charts the history of Goa and its economic and political relationship to the subcontinent. The whole of Portuguese rule is characterized by Rao as a "dark age." The revolts 
against Portuguese rule are emphasized while Goan collaboration with the Portuguese is largely ignored.

Three recently published surveys of the history of Portuguese colonialism in India share Rao's themes and concerns. One in particular, written by Sarto Esteves, a political scientist, describes the history of the Goan anticolonial struggle. Unfortunately, though the book is informative, it is dominated by hyperbolic statements that are difficult to take seriously, such as,

(Goa) was the first subject "nation" to raise its voice against political slavery and alien domination in the sixteenth century ... It is the Goans who in a way were the predecessors of a long line of political scientists and philosophers, and public leaders who later propagated the ideas of liberty, equality and fraternity, the right of every nation to be free and manage its own affairs and the basic freedoms every individual must enjoy to be able to develop his personality and contribute to the growth and flowering of every human being of the world. ${ }^{30}$

Despite these credentials Goans failed to revolt successfully against the Portuguese state. To explain this paradox Esteves states:

The main reason for this state of affairs appears to be that the Goan in general is too docile, complacent, selfcentered and law abiding a citizen. Loath to resort to revolutionary methods to achieve anything. He speaks the language of a gentlemen which seldom converged any meaning to a colonial power, much less to the Portuguese, and it is precisely that which was their undoing. ${ }^{31}$ 
Esteves's exaggeration of Goans' role in the creation of modern political thought is hyperbole and his simultaneous derision of Goans is unfortunate, but the book is nonetheless useful for its information.

Fortunately, Esteves's confused and exaggerated prose is not the salient feature of P.P. Shirodkhar's book. Shirodkhar, rather than lamenting Goan docility and complacency, writes:

With the turn of the twentieth century, while the movement for political liberties gathered momentum in India, a silent revolution was taking place in the Portuguese territories. The people in Goa, ... evincing keen interest in the liberation struggle on the mainland and trying to identify themselves with the Indians ... The silent movement for liberties which was slowly and gradually intensified, was in fact the consequence of the tug of war between two opposing forces. On the one hand, social, religious, cultural, historical and geographical affinity with India injected in the Goans a spirit of Indian nationality ... The growing liberation struggle inspired them to assert their own rights. On the other hand, the Portuguese rulers resorted to rigorous, repressive measures for suppressing the national awakening. ${ }^{32}$

Shirodkhar's argument, however, is not persuasive. Within British India many "national awakenings" and struggles to "assert rights" were welcomed with "rigorous, repressive measures" yet these movements gained momentum and generally persisted. So, Shirodkhar fails to explain adequately why a mass nationalist movement never emerged in Goa.

The last of the surveys of the Portuguese presence in India that mentions the Goa "problem" is M.N. Pearson's contribution. Pearson's book is perhaps the most balanced 
assessment of the Portuguese territories in India. Regarding the debate over Goa and the use of force, Pearson concludes: "neither side emerged with much credit."33

The classic histories of Portugal written or translated into English either support Salazar's stance or withhold judgment. H.V. Livermore defends Salazar's position concerning the takeover of Goa. He attributes the lack of support for Salazar among the British and American governments to the adoption of an anti-imperialist position by Marxists especially after the success of Mao's regime in mainland China. These Marxists sought, as Livermore puts it, to "fan nationalism and to turn the newly created states against the Western powers." ${ }^{34}$ Marxists, therefore, influenced the large groups of Afro-Asian representatives who declared "colonies" illegal in the United Nations Constitution. Within this atmosphere, the West was reluctant to act:

The conquest of Goa was soon completed, and the Russian delegate to the United Nations promptly stifled discussions by using his veto. Dr. Salazar expected a reaction of world opinion against the aggression, but Western policy was so confused that nothing was done. ${ }^{35}$

Livermore's accusations against Marxists and lack of thought regarding the ideological commitments of postcolonial nationalist movements are not the best examples of "objective" historical scholarship.

A.H. de Oliviera Marques's two volume history of Portugal refrains from accusing Marxists of plotting against the western world, but the volumes support Salazar's position implicitly. An example of this implicit support is Marques's strained rationalization for the use of the word "colonial" in Salazar's constitutional reforms: 
The word "colonies" meant little —a result of French influence ... rather than any new doctrine in administration. From a constitutional standpoint the "colonies" were considered part of the nation as before, ... In the Constitution of 1911 , as well as many other official texts, the word "colony" appeared along with the word province with obviously the same meaning. ${ }^{36}$

Although the word may have meant little to Marques, the two words do mean different things, the use of the word colony rather than province indicates at least a tension within the Portuguese government regarding the exact status of Portugal's overseas territories. Marques denial of the difference of meaning between province and colony may reveal his bias for Salazar's position. Incidentally, no one in the Portuguese government would ever refer to the Algarve or even the Azores as a colony. Despite Marques's statements the two words, colony and province, are not synonyms.

This Luso-centric historiography is only the most recent of a long tradition of Portuguese historiography that celebrated and ennobled the Portuguese Empire. ${ }^{37}$ Despite the constant assertion that the histories were objective and empirical they are flawed by an overt Luso-centric or an Indo-centric perspective. The Indo/Luso-centric historiography described above illustrates the role of historical narratives played in the attempts to sustain a national identity. To sum up, the historiography of Goa and the debate between Nehru and Salazar is flawed by two problems. First, all of the works focus their attention on the political negotiations between Salazar, Nehru and their respective allies. Although Rubinoff states that the debate was by and large an "abstraction" and of a "symbolic nature" he and the other scholars neglect to focus on the symbolic and abstract meaning of Goa. Second, the historiography is characterized by an Indo-centric or Luso- 
centric tone. The historiography concerning the case of Goa has been written largely by committed nationalists that confirms Renan's statement, "Getting its history wrong is part of being a nation" and Eric Hobsbawm's suggestion, "no serious historian of nations and nationalism can be a committed political nationalist." 38

The use of history in the politics of nationalism has become an important area of investigation among scholars of India. Barbara Metcalfe has said recently: "A striking characteristic of recent public life in India has been an intensified use of historical narratives to define the nature of Indias peoples and draw the boundaries of citizenship." 39 The use of historical narratives in the politics of identity was especially evident during the controversy over the Babri Mosque at Ayodhya. According to the histories composed and sponsored by nationalist Hindu parties, the mosque was built in 1528 on top of the supposed birthplace of Lord Ram, a Hindu deity. Following a prolonged and vain campaign to force the Indian government to remove the mosque, a mob of Hindu nationalists took it apart by hand. The communal violence ignited by this action was the worst in the subcontinent since the independence of Bangladesh.

Although Benedict Anderson's brilliant insight into the use of novels, newspapers and other forms of print by capitalism to form an "imagined community" is useful, he fails to fully explorenational histories produced in universities. In the mid-nineteenth century nationalism and the professionalization of history were not mutually exclusive events. Indeed, it is difficult to imagine the rise of nationalism without the corresponding rise of universities and the professionalization of history. Hobsbawm notes, "the progress of schools and universities measures that of nationalism, just as schools and especially universities became its most conscious champions." 40 Nicholas Dirks has noted: 
History has played a key role in the modern production of the nation-state and of the various constituent bases of nationality, at the same time that the nation has played a critical historical role in defining what a modern conception of history should be. ${ }^{41}$

Historical narratives occupy a very ambivalent position within the discourse of nationalism. A primordial or "hoary" past is usually invoked to provide a degree of continuity, yet there is the simultaneous demand to liberate the nation from the burden of history. History and historians have helped to create the illusion that, as Etienne Balibar put it:

the generations which succeed one another over centuries on a reasonably stable territory, under reasonably univocal designation, have handed down to each other an invariant substance. ${ }^{42}$

History, in this teleological sense is an idea through which the nation is conceived, articulated, and legitimized.

Prasenjit Duara has recently argued that this form of History, has had an intimate relationship with the development of nationalism. Nationalist and historical narratives present an apprehension of time and space which allowed the nation to be the central category used to understand the past, the present and imagine the future. Such narratives contributed to the "rhetoric of national affiliation." Some historians, especially those with nationalist objectives or bias, help to buttress the ideology of the nation-state by assigning a past to the imagined community. ${ }^{43}$ In other words, although a nation is a "timebound" idea which has to be sustained by a variety of strategies, historians have tended to ignore this problem and have taken the nation-state for granted. 
Partha Chatterjee has provided a rigorous study of the transmission of this ideology to the "people" that form nations. Chatterjee proposes that the concepts and methods associated with post-colonial and post-structural theory are useful means of understanding the paradoxes of nationalism. To understand how the Indian nationalists replaced the British, Chatterjee recruits Foucault's "discourse" to outline

an analytical framework in which the ideological history of the Indian state can be studied. The framework attempts to locate, within a historical context of "passive revolution", the problem of the autonomy of nationalist discourse as a discourse of power ... Nationalist texts were addressed both to the people who were said to constitute the nation and to the colonial masters whose claim to rule nationalism questioned. To both, nationalism sought to demonstrate the falsity of the colonial claim that the backward people were culturally incapable of ruling themselves in the conditions of the modern world. ... [Nationalism] has produced a discourse in which, even as it challenged the colonial claim to political domination, it also accepted the very intellectual premises of modernity on which colonial domination was based. ${ }^{44}$

Chatterjee defines the terms of the method of analysis in the following quotation:

[T] he thematic ... refers to an epistemological as well as ethical system which provides a framework of elements and rules for establishing relations between elements; the problematic ... consists of concrete statements about possibilities justified by reference to the thematic. ${ }^{45}$ 
The thematic, to use a familiar example, was the idea of the Orient and the Oriental as described by Edward Said in his classic book Orientalism; while the problematic was the taxonomy developed by Orientalists built around ethnicity, race, or peoples that produced the narratives of Orientalism. Chatterjee argues that this distinction will help to disentangle the paradox of nationalism. The ideology of nationalism is to be compared with the politics it produced, because, as Chatterjee put it: "The polemical content of nationalist ideology is its politics." problematic of nationalist discourse is its ability to make claims and to see them materialized:

political-ideological discourse does not consist only of claims: those claims also have to be justified by appeal to logical, epistemological and above all ethical principles. In politics, people have to be persuaded about not only the feasibility but also the legitimacy and desirability of ends and means. ${ }^{47}$

It is not enough for a nationalist leader to present the claim that the colonizer should be evicted and replaced by a group indigenous to the locale, but the leader must present a sustained argument to rally the "people" against the colonial administration. The benefits of de-colonization and its worth must be convincing to create a movement. The thematic of the nationalist discourse is "concerned with the relation between nationalist discourse and forms of modern Western thought." But this is a difficult procedure because nationalist texts must differentiate themselves from the colonial discourse. Nationalists were very selective when they adopted an aspect of Western thought. In other words, anti-colonial, nationalist discourse must differentiate its ideology from that of the colonial discourse otherwise it is simply mimicry. The thematic and the problematic, Chatterjee argues: 
[t]aken together, in its dialectical unity, ... enable us to show how nationalism succeeds in producing a different discourse. ... Its politics impels it to open up [a] framework of knowledge which presumes to dominate it, to displace that framework, to subvert its authority, to challenge its morality. ${ }^{48}$

Yet nationalist, anti-colonial discourse, as the subtitle of the book suggests, is derivative. The presence of this contradiction is understood by recruiting Gramsci's notion of "passive revolution."

Chatterjee proposes that the emerging self-conscious, Western-educated, Indian bourgeoisie could not attack the colonial state directly through military methods. It therefore had to adopt a "war of position." This means that the bourgeoisie had to struggle against two forces which prevented the modernization of India: the colonial state and the Indian groups which for whatever reason wished to preserve the status quo. So, the bourgeoisie had to convince a proportion of the population that the best way to modernize and yet preserve traditional India was to replace the colonial state with a national state. To accomplish such a task a series of alliances bridging and including the traditional and reforming factions of India had to be created and maintained. Thus, as Chatterjee put it: "the passive revolution acquires the dual character of 'revolution/restoration'." 49 By 1947 the Indian nationalist movement had reached its "moment of arrival" by persuading and coercing the colonial state, its collaborators and recruiting people into political organizations to organize protest marches and rallies. At these rallies and marches political and nationalist rhetoric was used to persuade them of the benefits of an independent nationstate. After independence had been achieved the antiimperial nationalist ideology developed into a state 
ideology based on secularism, social democracy, economic development and non-alignment.

In summary, nationalism is an "imagined community" and a discourse in which history plays a crucial role. Since the nineteenth century history had contributed to the rhetoric of nationalism. Rhetoric is a pejorative for many people; I want to emphasize the classic understanding of rhetoric as simply the use of language and oratory to persuade an audience. The rhetoric and discourse of nationalism in the colonial context may be understood by using Chatterjee's thematic and problematic framework of analysis. During the debate over Goa, sovereignty, national belonging and boundaries constitute the thematic, while the problematic involved how to persuade international and national audiences that Goa belonged to either Portugal or India.

How did Salazar defend his assertion that Goa, thousands of miles away from Europe, was a part of Portugal? In a speech presented to the Portuguese National Assembly on the 30 November 1954 he said:

The extension of Indian sovereignty to include Goa is not a prospect opened up by, or in anticipation of, the evolution of history; it is a political goal which India's present leaders suppose it their duty to achieve in order to fulfill their mission ... It is always historical facts, and not geographical outline, that fix frontiers, institute rights and impose sovereignties ... For the Indian Union to claim to turn the clock of history back to the XVIth century, to come forward now and make out that she already existed potentially at that time, or to set herself up as the rightful heir of those whom we found holding sway there, is a fancy of static dreamers; it is not for the dynamic shapers of history that the men who received an empire from England want to be. ${ }^{50}$ 
In response Nehru said in the Lok Sabha, the lower house of India's parliament,

although it does not require that anything should be said in justification of our claim to Goa, I shall, nevertheless, venture to mention a few facts ... There is of course the geographical argument. The Portuguese Government claims that Goa is a part of Portugal. That remark is so illogical and absurd that it is rather difficult to deal with ... It has no relation to facts ... I am not going into the old history of the Portuguese possession of Goa; but I think many members will remember that this history is a very dark chapter of India's history.

Moreover, on 17 September 1955, Nehru said:

In Goa, we have a remarkable picture of the sixteenth century facing the twentieth century, of a decadent colonialism facing a resurgent Asia, of a free independent India being affronted and insulted by the Portuguese authorities, of, in fact, Portugal functioning in a way which, to any thinking person, is so amazing in its incongruity in the modern world that he is a little taken aback. ${ }^{\text {s1 }}$

In my opinion, Nehru's confusion stemmed from Salazar's subordination of geography to history, and the wily dictator's refusal to accept India's past constructed by Indian nationalists. So, the imagined India created by nationalist historians, which Nehru described in The Discovery of India, was, according to Salazar, "a fancy of static dreamers." While Nehru ignored "the old history of the Portuguese possession" to focus on the "facts" rather than the "illogical and absurd." Ironically, Nehru also suggests Salazar was a "static dreamer" practicing a "decadent colonialism" of the sixteenth century. 
Now, we may begin to discuss the "facts" of this debate, followed by the "dreams." Goa and Portugal shared a 450 year history. Centuries of intermingling and shared experiences between the "peoples" of Portugal and Goa, Salazar argued, created a "distinct" culture in the subcontinent which was not Indian, but Portuguese. Academic respectability seemed to buttress Salazar's convictions. During the 1940s a well-known anthropologist from Brazil and a graduate of Columbia University, Gilberto Freyre, argued that the assimilationist policy of the Portuguese created a distinct culture and civilization which he labeled tropicalismo. This Portuguese international culture was based on hybridity: a mixture of pagan religions of India, Africa and South America and Portuguese Catholicism, which was itself the progeny of the interaction between Judaism and Islam and the mixture of the European and African "races." Due to this process the Portuguese were, in contrast to the other Europeans, especially the English, non-racist and tolerant. Tropicalismo was of course a grotesque exaggeration, but it was a widely accepted notion. More research is needed to establish whether or not a link between Freyre and Salazar's government existed. ${ }^{32}$

Nehru, on the other hand trusting the common sense of geography, simply declared that Salazar's position was "illogical", "absurd" and that it had "no relation to facts." Moreover, while Nehru agreed with Salazar that Goa had indeed a separate identity, which he had "no intention of changing ... or suppressing." Nehru argued that Goa was part of India. It was "obvious" and did not require any persuasion. One simply had to consult a map. The history of the colonization of Goa was a part of India's "dark" past which is ignored and contrasted against a static, "decadent" colonialism rooted in the sixteenth century. India, of course was a "resurgent" actor of twentieth century Asia and the world. So, Nehru, the keen amateur 
historian who preferred to read history to fiction, ignored history to emphasize the logic of geography and cartography.

What is the place of Goa in Nehru's and Salazar's nationalist "dreams"? An answer to this question may be found in the metaphors used to describe Goa. Indian nationalists were fond of describing Portuguese India as "the pimple on the face of Mother India." The pimple is of course an unattractive, small, foreign growth on the surface of the skin, but it eventually disappears over time. A pimple is a temporary nuisance. Salazar's allies, however, preferred to use, "Rome of the Orient." The phrase joins two sites, "Rome" and the "Orient," that are considered by many to be eternal, outside of time or timeless, and yet are distinguished by their centuries long continuous histories. The metaphor also implies the coupling of "East" and "West" - the hybridity of Freyes's tropicalismo. The distinction between temporary time and eternal time is characteristic of the rhetoric of nationalism: nations are eternal with a "hoary" past, while empires are fleeting, victims of time.

Salazar's and Nehru's nationalism were dreams of redemption from an unfortunate past and the hope for an utopia possible only through their nation. For Salazar Goa represented a link to Portugal's glorious past and its mission civilisatrice which he hoped would restore to Portugal a position of respect among the international community. While for Nehru, Goa represented the last visible presence of colonialism on the subcontinent. Goa was a painful reminder of a dark past. Salazar's nationalist rhetoric challenged Nehru's assumptions about the relationship between empires and nations thus reducing Nehru's speeches to expressions of bewilderment. After 14 yearsof stalled negotiations and increasing pressure from his political opponents, and with his anti-colonial 
credentials in jeopardy, Nehru abandoned diplomacy and ordered the military to "liberate" Goa.

The conflict between geography and history, and nationalism and imperialism was resolved by the successful military takeover of Goa. In this context Nietzsche's definition of truth - "a mobile army of metaphors ... truths are illusions of which one has forgotten that they are illusions"-seems to be appropriate for the concerns of this article. ${ }^{33}$ When the "mobile army of metaphors" failed to persuade Salazar and the Goans themselves a "real" army accomplished the task. How the illusion of the tangible or "real" existence of a nation is engendered among a significant proportion of the population is a question that I cannot answer completely. But the dissonance between Salazar's and Nehru's rhetoric and the Goan's silence suggests that armies of metaphors or soldiers do not create "imagined communities" by themselves. To persuade a community that they are in fact a nation, rhetoric and its weapons or tools must be linked to the often mundane and thankless task of organizing groups of people to form a legitimate constituency.

Recent scholarship on nationalism has neglected to consider this process. The debate over Goa and the failure of nationalist rhetoric therefore suggests that scholars interested in nationalism and nations must turn to those individuals and groups who actually organized people into nations. The recent emphasis on the cultural and political elites that write histories, poetry and novels about nations fails to account for the dissemination of the idea of national affiliation. This does not mean however that scholars of nationalism should abandon the texts of nationalist rhetoric. Histories are probably the most effective rhetorical tools used or abused by nationalists, and historians have much to learn from the reading and critical techniques and terms associated with post-colonial studies. Historians perhaps have the most to gain from adopting these techniques 
because their discipline is perhaps the most enslaved to the nation as an analytical and descriptive category. Yet the nation is the most ubiquitous phenomena of late modernity. History has recently become a dangerous form of inquiry in India and other parts of the world. History books, as Hobsbawm has recently stated, "can turn into bomb factories" that help to produce explosive situations in many parts of the world..$^{54}$ Historians, therefore, interested in nationalism may enter into a useful dialogue with post-colonial criticism to separate their craft from the rhetoric of nationalism.

\section{NOTES}

${ }^{1}$ The most recent example of this is a article titled "Goa: the India of Churches, coconuts" The Globe and Mail, 7 September 1996, A12. The first sentence of the article is "Goa is India, and Goa is not India."

${ }^{2}$ M.N. Pearson, The Portuguese in India (Cambridge: Cambridge University Press, 1987), 160-61

${ }^{3}$ Stanley Fish, Doing What Comes Naturally: Change, Rhetoric and the Practice of Theory in Literary and Legal Studies(Durham, NC: Duke University press, 1989), 472-79.

"Tom Naim, "The Modern Janus," The New Left Review 94 (1975): 3-29.

"The uppercase " $h$ " in History indicates a philosophy of history clearly influenced by Hegel and that is common to both Marxist and non-Marxist historiographies. It is a teleological and linear model of understanding the past. For more information see Prasenjit Duara, Rescuing History from the Nation: Questioning Narratives of Modern China (Chicago:University of Chicago Press, 1995), 17. 51.

${ }^{6}$ For an interesting and thought provoking analysis of this process see Teresa Hubel, Whose India? The Independence Struggle in British and Indian Fiction and History (Durham: Duke University Press, 1994), especially the first chapter.

' Jawarharlal Nehru, The Discovery of India (Delhi: Oxford University Press, 1946), 562-63.

${ }^{8}$ Ibid., 515.

Ibid., 479. 
${ }^{10}$ Nationalism is conceived by many scholars to be part of Modernity. A useful definition of Modernity is provided by David Harvey. Modernity is characterised by two notions. First, "modernity can have no respect for its past ... [or] pre-modern social order. Modernity, therefore, not only entails a nuthless break with any or all preceding historical conditions, but ischaracterized by a neverending process of internal ruptures and fragmentations within itself." Second, this break is necessary to fulfill the Enlightenment Project which is to create an immutable, rational, egalitarian society based upon the value free methodology of science. See David Harvy, The Condition of Postmodernity (Cambridge: Blackwell Publishers, 1990), 10-14. An examination of the Enlightenment Project, Modernity and nationalism, see Partha Chatterjee, Nationalist Thought in the Colonial World: A Derivative Discourse? (London: Oxford University Press, 1986), 1-30.

"Sarto Esteves, Politics and Political Leadership in Goa (New Delhi: Sterling Publishers, 1986), 24; and P.D. Gaitonde, The Liberation of Goa: A Participant's View of History (New York: St. Martin's Press, 1987), 3-4.

${ }^{12}$ For information on Mesmerism and its relationship to the French Revolution, see Robert Darnton, Mesmerism and the End of the Enlightenment in France (Cambridge: Cambridge University Press, 1968).

${ }^{13}$ Pearson, The Portuguese in India, 147.

"Quoted in A. H. de Oliveira Marques, History of Portugul: From Empire to Corporate State. Vol. 2, (New York: Columbia University Press, 1972), 91.

"s Pearson, The Portuguese in India, 147.

${ }^{16}$ Esteves, Politics and Political Leadership in Goa, 14.

${ }^{17}$ Ibid., 16.

${ }^{18}$ This incident is described in P.D. Gaitonde, The Liberation of Goa, 6.

19 Esteves, Politics and Political Leadership in Goa, 35

${ }^{20}$ Gaitonde, The Liberation of Goa, 14.

${ }^{21}$ Esteves, Politics and Political Leadership in Goa, 37.

${ }_{22}$ T.B. Cunha, Goas Freedom Struggle (Bombay: New Age Printing Press, 1961).

${ }^{23}$ Arthur Rubinoff, India's Use of Force in Goa (Bombay: Popular Prakashan, 1971), 29.

24 Ibid., 30, 39.

${ }^{2 s}$ Jose Freire Antunes, "The Fall of Goa," Camoes Centre Quarterly 4 (1992-93): 29-38. 
${ }^{26}$ Ibid., 29. In 1955, John Foster Dulles, the American secretary of state, said at a news conference: "As far as I know the world regards it [Goa] as a Portuguese province. It has been Portuguese, I think, for about 400 years." In American Foreign Policy Current Documents 2(1950-55): 2294.

${ }^{27}$ B.S. Shastry, "A Sovereign Republic of Goa: A Fallout of Partition and Independence," Indo-British Review 17 (1989): 143.

${ }^{28}$ Habibar Rahman, "India's Liberation of Goa and the AngloAmerican Stand," South Asia 19(1996): 37-48.

${ }^{29}$ R.P. Rao, Portuguese Rule in Goa (Bombay: Asia Publishing House, 1963).

${ }^{30}$ Esteves, Politics and Political Leadership in Goa, v-vi.

${ }^{31}$ Ibid., 55.

32 P.P. Shridokhar, Goa's Struggle for Freedom (Delhi: Ajanta Publications, 1988), 23.

${ }^{33}$ Pearson, The Portuguese in India, 160.

${ }^{34}$ H.V. Livermore, Portugal: A Short History (Edinburgh: Edinburgh University Press, 1973), 194.

"Ibid.,196.

${ }^{36}$ Marques, History of Portugal, 225.

${ }^{37}$ Luso is a synonym of Portugal derived from Lusus, the name of the legendary founder of the Kingdom of Lusiads, sons of Lusus. Lusitania is also the name assigned to a similar geography controlled by the Romans.

${ }^{38}$ E.J. Hobsbawm, Nations and Nationalism Since 1790: Programme, Myth, Reality (Cambridge: Cambridge University Press, 1992), 12; Ernest Renan, "What is a Nation?," in Nation and Narration, ed. Homi Bhabha (London: Routledge, 1990), 822.

"Barbara Metcalfe, "Too Little, Too Much: Reflections on Muslims in the History of India," Journal of South Asian Studies 54 (1995): 952.

${ }^{10}$ Ibid., 166.

"Nicholas Dirks, "History as a Sign of the Modern," Public Culture 2 (1990): 25.

"Duara, Rescuing History from the Nation, 27-33. Etienne Balibar has also noted this problem in the discourse of nationalism in his essay "The National Form: History and Ideology," in Race, Nation, Class: Ambiguous Identities, eds. E. Balibar and I. Wallerstien (London: Verso, 1991), 86.

${ }^{43}$ Historians have begun to examine this issue. Two of the most interesting examples are Eric Hobsbawm and Terence Ranger, The Invention of Tradition (Cambridge: Cambridge Univeristy Press, 
1992); and Sudipta Kaviraj, "The Imaginary Institution of India," in Subaltern Studies: Writings on South Asian History and Society, eds. P. Chatterjee and G. Pandey (Delhi: Oxford University Press, 1992).

${ }^{4}$ Chateriee, Nationalist Thought and the Colonial World, 30.

15 Ibid., 38.

${ }^{46} \mathrm{Ibid} ., 40$.

${ }^{47}$ Ibid., 41.

${ }^{48}$ Ibid., 42.

"Ibid., 49.

so Antonio de Oliviera Salazar, The Case for Goa (Lisbon: Secretariado Nacional da Informacao, 1954), 3-5, 8.

st Jawarhalal Nehru, Indias Foreign Policy: Selected Speeches: September 1946 to April 1961 (Delhi: The Commercial Printing Press, 1961), 112, 120.

"For a recent discussion of Freyre's work and influence see Jeffrey

D. Needell, "Identity, Race, Gender, and Modernity in the Origins of Gilberto Freyre's Oeuvre," American Historical Journal, 100 (1995): 51-77.

${ }^{3}$ Friedrich Nietzsche, Friedrich Nietzsche on Rhetoric and Language, eds. and trans. Sander L. Gilman et al. (New York and Oxford: Oxford University Press, 1989), 250.

${ }^{54}$ Eric Hobsbawm, On History (New York: The New Press, 1997), 5. 